THE ANT PRENOLEPIS IMPARIS SAY

BY

WilitaM MORTON WHEELER.

REPRIMTED FROM

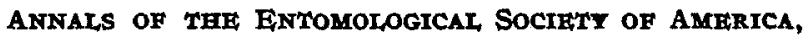

Vol, XXIII, No. I.

Columbo, Orio,

March, 1930. 


\title{
THE ANT PRENOLEPIS IMPARIS SAY.*
}

\author{
William Morton Wheeler, \\ Harvard University.
}

To the myrmecologist the ants that belong to the ancient preglacial circumpolar fauna are of unusual interest, and among these none is more deserving of study than the small, shining, brown or yellowish Prenolepis imparis, because it is almost indistinguishable from $P$. henschei Mayr, a species that flourished in the amber forests of the Lower Oligocene Tertiary of northern Europe. In addition to its great antiquity and its extraordinary morphological stability throughout postoligocene time, $P$. imparis also exhibits certain behavioristic peculiarities which have not been sufficiently emphazied in the literature.

\section{A. Distribution and Ethology of P. imparis.}

As redefined by Emery in 1906, the genus Prenolepis contains only eight described species, namely acuminata Forel of Mexico, gibberosa Roger of Cuba, imparis Say of North America, jerdoni Emery of Indomalaya, melanogaster Emery of Upper Burma and Indochina, nitens Mayr of Europe, naoroji Forel of Hindoustan and the above-mentioned fossil species henschei of the Baltic amber. This list, however, will have to be reduced because acuminata is very probably a Paratrechina and not a Prenolepis, and nitens, as I shall show, is a mere variety of imparis. Furthermore, imparis itself is scarcely more than a variety of the extinct henschei. At any rate, the neotropical and paleotropical species gibberosa, jerdoni, melanogaster and naoroji are quite different from the group com-

*Contributions from the Entomological Laboratory of the Bussey Institution, Harvard University, No. 319 . 
prising the very closely interrelated imparis, nitens and henschei. Of course, the wide and discontinuous distribution of its various species is an argument in favor of the great age of the genus Prenolepis, which may actually have had its origin during the Eocene or Cretaceous.

Say described $P$. imparis ("Formica imparis") as long ago as 1835 from male and female specimens taken in copula in Indiana. The specific name obviously refers to "the great disparity in color and magnitude between the male and female." Mayr described nitens in 1852 as a Tapinoma, but in 1861 made it the type of his genus Prenolepis. Opinions on the status of this form have varied. Dalla Torre (1893) and Ruzsky (1905) regarded it as a variety, and Emery (1910) as a subspecies of imparis, but in 1916 he raised it to specific rank, citing as his reasons the circumscribed geographical range of nitens, the stouter body and shorter appendages of its worker and the more heavily infuscated wings of its sexual forms, as compared with imparis. He was unable to detect any noticeable differences in the male genitalia.

$P$. nitens is confined to a limited area (shown in the map Fig. 1 B), as will be seen from the following data: Mayr records it from Tyrol, Carinthia, Transylvania and Dalmatia; Roger from Croatia, northern Turkey and Constantinople; Forel from Herzegovina, Albania, Cattaro, Corfu, Attica in Greece, Lesbos. and Bulgar Dagh, in Asia Minor; Santschi from Roumania and Ruzsky from the western Caucasus and the Black Sea district. It just enters Italy at the head of the Adriatic, occurring, according to Emery at Palmanova. More recently Finzi has found it near Trieste in Venezia Julia and on the island of Cherso, off the Dalmatian Coast. It would seem, however, that $P$. nitens must be a rather rare or sporadic ant, because its citation in recent lists of Formicidæ from the Caucasus, Balkan Peninsula and Asia Minor is very infrequent. In some of the older literature it is recorded as occurring in a few localities in western Europe. In $1855 \mathrm{~F}$. Smith described an ant as Tapinoma polita, later regarded as a synonym of $P$. nitens, from a single worker specimen captured at Bournemouth, England, and Bingham (1906) recorded nitens as living in the tropical fern house of the Kew Botanic Gardens. According to Bos (1887) both von Vollenhoven and Ritsema recorded this ant from the Leyden Botanical Garden. Donisthorpe (1908) 
could no longer find it at Kew and Blote (1924) failed to find it in Leyden. It was obviously introduced into both botanical gardens with plants or soil, and it is now impossible to state whether the form was really nitens from Eastern Europe or the typical imparis from North America. The workers of the two forms are so similar that even an expert myrmecologist might fail to distinguish them. I possess three workers and three

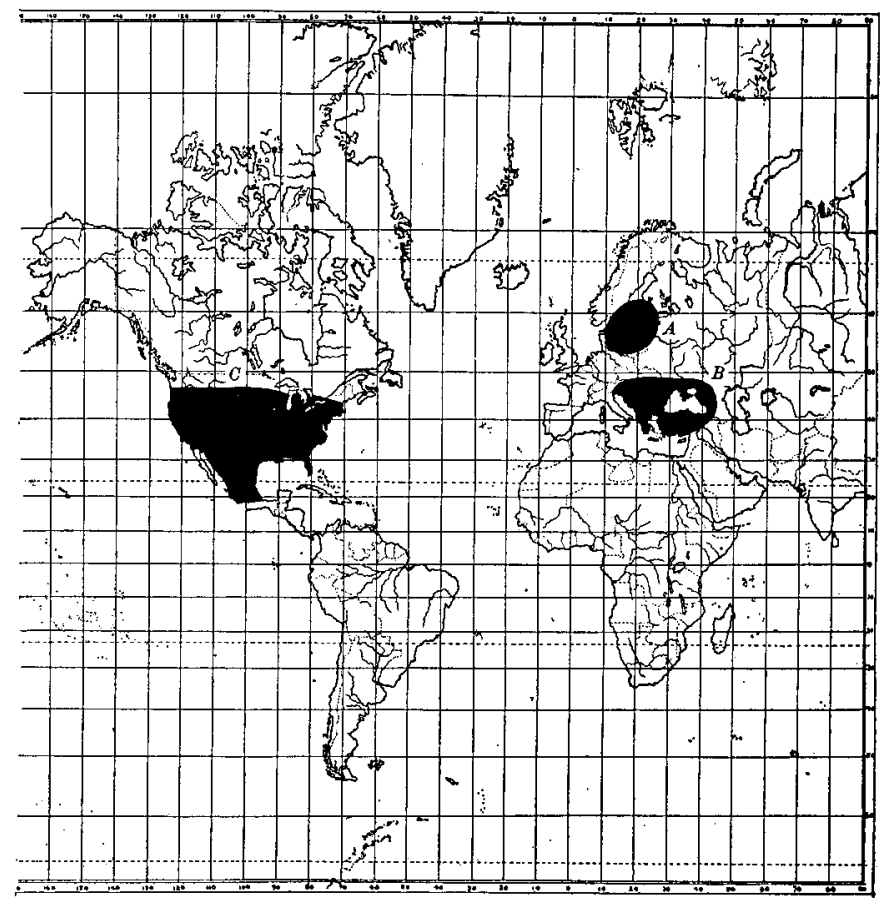

Fig. 1. Distribution of Prenolepis. A, P. henschei Mayr of the Baltic amber; B, P. imparis var. nitens Mayr; C, $P$. imparis sens. str. and its North American varieties.

males of the typical nitens from Lesina, Dalmatia, received many years ago from G. Mayr. The workers are indistinguishable from dark forms of imparis from the Atlantic states and though the wings. of the males are somewhat darker than in most forms of imparis, there are western varieties with wings of the same color as nitens. The present circumscribed or discontinuous distribution of the latter is no reason for regarding it as a distinct species, since the same argument would require 
us to regard the North American and Eurasian forms of Camponotus herculeanus, C. carya, Formica sanguinea, $F$. fusca, Leptothorax acervorum etc. as distinct species. In the case of $P$. imparis and nitens the discontinuity of distribution is merely greater.

A study of the American specimens of $P$. imparis that have been accumulating for many years in my collection, shows a remarkably wide distribution, covering nearly the whole of the United States, at least a portion of Ontario and the highlands of Mexico as far south as the states of Vera Cruz and Colima. In general, therefore, the range of the species in North America extends from lat. $19^{\circ}$ to about $46^{\circ}$. Emery (1893) distinguished three forms of imparis: the type, a var. testacea and a var. minuta, and I have described in the sequel six additional varieties-pumila, californica, arizonica, coloradensis, veracrusensis and colimana. All of these and Emery's varieties are based on rather feeble and elusive characters and are in part connected by intermediate forms, so that the species as a whole may be said to exhibit little morphological variation though it is sufficiently unstable in such characters as stature, pilosity, and color to permit recognition of certain feebly differentiated geographical forms (subraces).

Very little is known concerning the habits of the var. nitens. Finzi (1921) found it to be rather common in certain localities under stones in very moist places. The American forms, according to my observations, very rarely nest under stones, but make obscure crater nests, usually with a single small orifice, in shady places.* The typical imparis prefers moist, clayey soil, the var. testacea sandy soil or pure sand. The nests occur so frequently near oaks, even if they belong to our dwarf "scrub" species, that one suspects some definite association between the ants and these plants. Moreover, the general range of imparis and the oaks in North America is nearly conterminous, though the latter extend somewhat farther south (to Gautemala) and somewhat farther north (to Nova Scotia). Yet even within its general range imparis seems to be lacking over considerable areas, especially in the Rocky Mountain region. Much more intensive observation in the field will be required before its precise ecological distribution

\footnotetext{
*Dr. A. H. Sturtevant has recently informed me that the variety described below as californica regularly nests under stones.
} 
can be determined. This is difficult, because the ant is very timid and retiring and perhaps to some extent crepuscular or even nocturnal. At least it seems to avoid the open sunlight and to be most active in the shade and on cool or cloudy days. I have found the young deälated queens, which closely resemble those of Lasius niger, founding independent incipient colonies in small chambers in the soil.

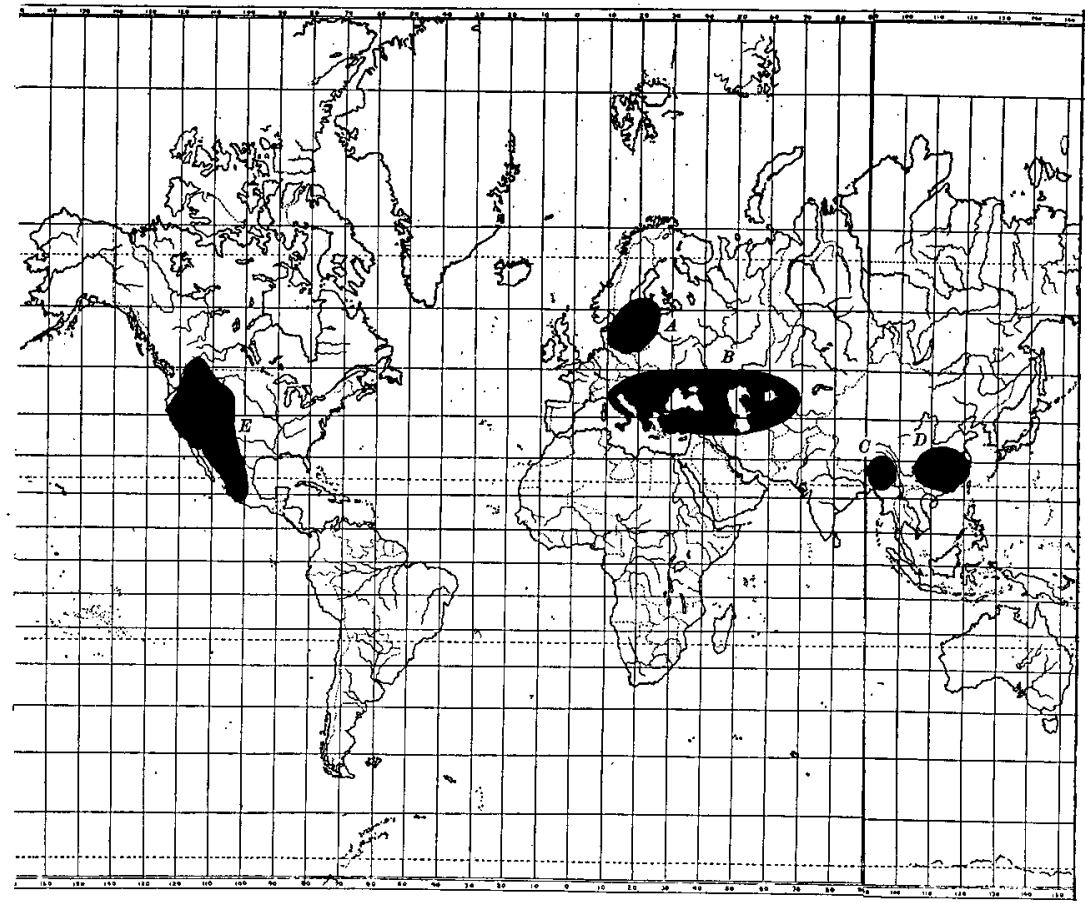

Fig. 2. Distribution of the species of Liometopum. A, L. oligocenicum Wheeler of the Baltic amber; B, L. microcephalum Panzer; C, L. lindgreni Forel; $\mathrm{D}$, L. sinense Wheeler; E, Distribution of L. apiculatum Mayr and occidentale Emery, covering the area of the fossil species L. miocenicum Carpenter and scudderi Carpenter in the Miocene of Colorado.

The food of $P$. imparis consists of liquids, especially the "honey-dew" of aphids and coccids, the nectar of flowers and extrafloral nectaries, the exudates of living oak-galls, the juices of dead earthworms and those derived from the young tissues of plants. These various liquids are imbibed in such quantities by the foraging workers that their gasters become 
greatly distendec. (Fig. 3) and make their gait very unsteady. In this condition they are really "repletes" like those of the true honey-ants of the Southwestern States and Mexico (Myrmecocystus melliger and mexicanus). The feeding of imparis (var. californica) on young plant-tissues has been recently called to my attention by Mr. H. M. Armitage and indicates that these small timid ants may become of some economic importance. He writes me that in Los Angeles County, Cal., they "were observed feeding extensively not only on the calyx and unopened petals of fruit buds of oranges, but also on the tender new growth. This condition was credited to the fact that the ants become active before the normal citrus bloom and at a time when little natural feeding was available." Mr. A. C. Burrill has recently made very interesting observations on the feeding habits of imparis and its singular resistance to cold in the Arnold Arboretum at Forest Hills, Mass., and in Missouri, and permits me to quote some of his unpublished notes:

"I was led to make continuous observations on $P$. imparis after casually noticing that it appeared at the surface of the soil later in the fall and earlier in the spring than any. of our other ants. During the rather warm winter of 1927-28 I selected for daily observation a nest with two entrances in the Arnold Arboretum. The workers were observed to come out onto the surface of the soil nearly every week throughout the winter. The lowest temperatures recorded when the ant came out were on February 6, 1928, when the temperature in the early morning was $6^{\circ} \mathrm{F}$. $\left(26^{\circ}\right.$ below freezing). At noon, less than eight hours later, a worker appeared at the surface though the soil was still frozen. On February 25 a worker passed from one entrance to the other with a sharp wind blowing at $27^{\circ} \mathrm{F}$., as recorded by a tested thermometer at one inch above the ground. The sun, however, induced a thaw, so that the temperature of the ground was really $33.5^{\circ} \mathrm{F}$. Tests with honey enticed more of the workers out of doors till the surface cold had fallen to $30^{\circ} \mathrm{F}$, when the surface of the soil was frozen and the ants brushed against hoarfrost around their entryway. Honey does not freeze at such a temperature and ants can still lap it up slowly.

"On cool, humid middays below $60^{\circ} \mathrm{F}$. workers may remain active above ground all day, but seldom stay in the bright 
sun or on dry soil. They are at their best during or after cold rains, or a cold, humid period with overcast skies. They were most active outdoors between $35^{\circ}$ and $55^{\circ} \mathrm{F}$. all winter, but they occasionally crawled over the soil below $30^{\circ} \mathrm{F}$. or above $60^{\circ} \mathrm{F}$. One case of great activity occurred when a colony moved to a new site during a drizzle and kept excavating the new nest down into the subsoil with air-temperature about $60^{\circ} \mathrm{F}$.

"For about five months these ants lived on dead or dying earthworms driven above ground by rains. If other food was

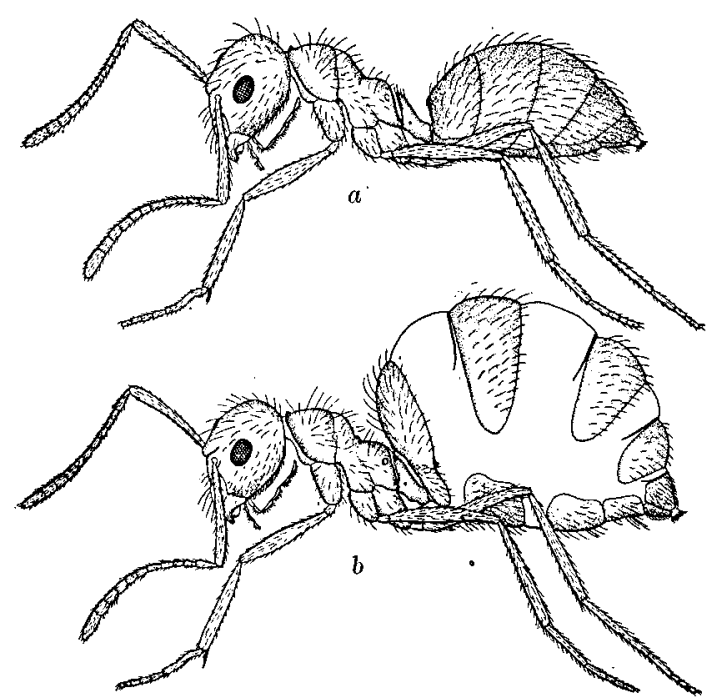

Fig. 3. Prenolepis imparis Say. $a$, worker in ordinary condition; $b$, same in the "replete" condition.

available besides honey-dew or honey that had been stored in the crops of the repletes during the fall, I failed to discover it. I often saw imparis leave an earthworm that had been dried up by the sun and return to it as soon as another rain had soaked it up again.

"Similar observations were made in regard to the winter activities of imparis at Jefferson City, Mo., during the winter of 1928-29. The ants were nesting in trodden, clayey, poorly drained loess soil. The workers were excavating December 14,15 and 16 , which were followed by a heavy freeze-up." 
Mr. Burrill's observations show that the ants do very little excavating during the winter but that this sets in suddenly a few days before the nuptial flight. This, as I have frequently noticed, takes place as early as the latter fortnight of March or the first fortnight of April. That the period must be much the same for the different varieties and over a considerable portion of the United States is indicated by the following dates of nuptial flights recorded in my notebooks, on the labels of mounted males and winged females or in the literature:

$P$. imparis (typica1). Forest Hills, Mass., March 15 and 25; Apri1 4, 5 and 6;

Bridgetown, N. J., March 28; Albany, N. Y., March; Wauwatosa, Wis., April

20; Jefferson City, Mo., March 19, 20 and 21; Lawrence and Riley Co., Kansas, March, April 2.

var. testacea. Bronxville, N. Y., April 10; Plummer's Island, Maryland, Apri1 12. var. minuta. District of Columbia, Apri1; Cape May, N. Y., March 24.

var. californica. Stanford University, Ca1., Jan. 30, Feb. 23, and March 19.

The winged sexes that participate in the nuptial flights mature during the late summer of the previous year and are retained in the nests over winter. I have found males and winged females of the var. testacea at Lakehurst, N. J. in the nests on September 24. This retention of the sexual phases over winter occurs in a few of our other northern ants, e. g. in the various varieties of Camponotus herculeanus and of.C. caryce, but in these cases the flight is later, usually in May or June, or even in July. The very early flight of imparis was first observed in Indiana by Say., who says: "They appeared in great numbers on the 2nd of April; the males swarmed around small bushes, alighting on the branches and leaves. The females were few." I have seen such flights of the males about the Japanese barberry bushes in the Arnold Arboretum on fine days in late March and early April. The males dance up and down in rather compact swarms like the late summer swarms of male bees of the genus Chloralictus.*

*The date and form of the marriage flight in ants are really specific characters and are clearly adaptations to the ecological conditions. Kusnezov-Ugamsky $(1927,1929)$ has called attention to certain peculiarities in the flights of ants in the deserts of Turkestan. He finds that they are very unfavorable to the flights at certain seasons, especially during the summer, probably, I surmise (I cannot read the Russian text), because the soil is then too dry and hot and the young recently fecundated queens are unable to dig deeply into it, or because the winds are too severe and make mating difficult. The species of Messor (rufus and barbatus), which are completely adapted to a desert life, therefore have their flights in the early spring (March and beginning of April), after overwintering the males and females in the nest. In the exquisitely deserticolous species of Cataglyphis the marriage flight has been suppressed. The females leave the nests singly and run 
Both Burrill's observations on its activity during the winter months and those on its very early nuptial flight indicate that $P$. imparis may be regarded as negatively thermotropic, or adapted to cold, unlike our other ants which are distinctly thermophilous, or thermotropic. $\dagger$ This is also indicated by the nesting habits of imparis. There are numerous observations on the hibernation of some of the more common ants of the north temperate zone. The behavior of most of them during the cold months is like that recently described by Holmquist (1928) in his study of Formica ulkei in northern Illinois. He found in this species that the activity of the workers at the surface of the nest declined gradually from September 10 to November 1 , after which date they remained dormant in clusters in their galleries below the frost line. On April 2, as soon as the frost had disappeared from the ground they gradually revived and returned to the surface but it was not till May 14 that the hibernation aggregations had completely broken up. "The hibernation period of this species was a prolonged one ( 5 to 8 months). The winter of 1924-25 was not unusually long for the Chicago region, and it is assumed that

about or skip nimbly over the surface of the soil with the aid of their wings like Pompilid wasps. I have also observed this peculiar behavior of Cataglyphis species in June and July in the desert regions of Morocco and Southern Spain. Kusnezov-Ugamsky believes that the absence from the deserts of Turkestan of whole genera, such as Formica, Lasius and Myrmica, is due to the fact that their species have stabilized their flight for midsummer and it is precisely at this season that the desert offers the most unfavorable conditions. My observations on the ants of our Southwestern deserts cio not agree with Kusnezov-Ugamsky's interpretation, except in the case of Veromessor, which is very closely related to the Old World Messor. I have found many males and winged females in the nests of $V$. pergandei as early as March 9 and April 20 , so that they must winter over and fly in the spring, but the sexual forms of Novomessor cockerelli and albosetosus do not develop until early June. Various species of Pogonomyrmex have their marriage flights from June to August in the deserts of Texas, Arizona and California, and I have described (1917) those of Moellerius versicolor and the nestfounding of recently fecundated queens of Myrmecocystus melliger mimicus in the Arizona desert on July 30. This was just after a cloudburst, however, when the soil was very damp and the air was clear and still. I believe that the conditions for summer marriage flights of ants, owing to occasional rains at that season, must be much more favorable in our American deserts than in those of Turkestan.

$\dagger$ The number of insects that remain active out of doors at low temperatures during the late fall, winter and early spring has been underestimated. Frison (1927) has called attention to this in his valuable paper on the fall and winter stoneflies (Plecoptera). It is significant that these as well as the more famous species of Boreus and Chionea and Desoria glacialis, the "glacier flea," all belong to very primitive groups. Miss N. Ford (1926) has called attention to the resistance to cold of Grylloblalta campodeiformis, another ancient form: "If placed in a large vessel containing pieces of ice the insects keep close to the ice, on it or under it, and as the ice melts, forming miniature streams, the Grylloblattæ readily wade them." 
this period is normal for this species. As compared with the hibernation period of most insects it is a long one." Steiner (1925) has shown that the temperature of dormant, hibernating aggregations of Formica rufa and Lasius niger in Switzerland is essentially that of the surrounding soil. In a later paper (1929) he demonstrates that while in bees and to a less extent in social wasps the nest-temperature is determined by the physiological, or body heat produced by the insects themselves, this is not the case in $F$. rufa and exsecta, but depends on the structure of the nest as an arrangement for securing and conserving the physical heat, or that due to diurnal insolation. The latter even in mound nests, like those of rufa, is retained only during a portion of the night, whereas in nests that are merely mined in the soil (crater nests), the heat of insolation is lost at nightfall.

These facts sead to a consideration of the differences between mined, or crater nests and those excavated in the soil under stones, and suggest that the exclusive occupation of crater nests. in moist, poorly drained soil in the shade may be regarded as a further indication of the negative thermotropism of $P$. imparis. I have already mentioned the fact that this ant, in Eastern North America, almost never lives in nests under stones. Now the great majority of temperate region ants live either in crater nests or in the soil under stones and the prevalence of one or the other according to temperature and humidity presents an interesting and complicated ecological problem. In the desert regions of Africa, Asia, North America and Australia the crater nest is the common and often the only type of nest observed (see also Kusnezov-Ugamsky 1925). In such regions there is no need to conserve the heat of insolation in the nests. The soil temperature, in fact, is often too high for the comfort of the ants, so that they suspend all activities at the surface, remain in the depths of their galleries during the hottest hours of the day and forage only in the cool of the morning or evening or at night.

Forel (1874) was, I believe, the first to call attention to the great prevalence of nests under stones at high elevations in the mountains and his observations have been confirmed by Steiner (1929), who has given a careful analysis of this type of nidification. Stones that are not too small are very advantageous at high altitudes because they protect the nest from wind and other inclemencies of the weather, the too rapid evaporation 
of moisture from the soil beneath them and above all, because they are rapidly heated by the sun and transmit their heat to the surface galleries. They have the disadvantage, however, compared with the mounds of vegetable débris accumulated by such ants as Formica rufa, exsecta, etc. in losing their heat rapidly by radiation after nightfall. Nevertheless, nests under stones are very common also in rather dry climates even at low altitudes, as in many parts of the United States. Indeed, many of the common circumpolar species nest in this country under stones, though the same or closely allied forms in Central Europe, where the soil and atmospheric humidity is greater, prefer to construct small mound nests or those with at least some accumulation of earth or débris over the excavated galleries to act as capturers and storers of the feebler heat of insolation and thus serve as incubators for the brood during the early summer months. Quite a number of ants, however, nest under stones in the shade of woods, thickets, etc. Some of our species, like those of the genera Ponera, Stigmatomma, Myrmecina, Stenamma, Aphaenogaster, Brachymyrmex, all Acanthomyops and some Lasius, require only moderate warmth and the shaded stones probably take up from the air and transmit to the soil sufficient heat during the breeding season. These ants, however, seem to demand a greater or more equable soil moisture than those which nest under stones exposed to the sun. I have introduced this digression as tending to throw the singularity of $P$. imparis into stronger relief, since this ant, as a rule, merely mines its nests rather deeply into damp, shaded soil and fails to take advantage even of the slight heatstorage of the stones that are often found in its immediate environment.

Besides its cryophily, or negative thermotropism there are two other negative peculiarities of $P$. imparis worth mentioning. One is its failure to keep root aphids or coccids in its nests, like the species of Lasius, Acanthomyops and Brachymyrmex so common in the same situations. This may seem surprising, because imparis is so fond of honey-dew, till we consider that the habit of keeping root Homoptera is probably amply compensated by its ability to develop repletes capable of storing large quantities of liquid food. It is not so easy to account for the fact that the nests of an ant so defenceless and so addicted to feeding by regurgitation, contain no guests or 
myrmecophiles. At least there is no record of such an occurrence, though imparis is very common in the Atlantic States where coleopterisits and other entomologists have long been searching the nests of our various Formicidæ for myrmecophiles. In this connection the occurrence of pseudogynes in Prenolepis is interesting. In 1914 I described two pseudogynes of $P$. henschei from the Baltic Amber and more recently have found one of $P$. imparis var. testacea among some workers from Georgia. Though apparently very rare, the occurrence of such pathological stages between female and worker are worthy of note, because their presence can hardly be attributed to the infestation of the colony with larva-devouring symphiles, as in the case of the famous pseudogynes of Formica sanguinea.

If it be true, as I believe, that the American and Eurasian forms of $P$. imparis are scarcely more than varicties of the Upper Oligocene henschei, we may suppose that the latter had a wide circumpo ar distribution during the Early and Middle Tertiary and that the living forms represent the remnants of that fauna after its southward displacement by the Pliocene glaciation. This is also Emery's opinion (1920). He accounts for the present distribution of the var. nitens on the supposition that it was extemminated north of the Alps, which formed a barrier to its scuthward migration in western Europe, but managed to survive in the southeast by escaping through the gap between the Balkan Alps and the Caucasus. P. nitens is therefore a glacial relict which, after the return of a milder climate, has spread over the limited area it now occupies. In North America, on the other hand, the north-south trend of the mountain ranges permitted a more extensive southward migration, survival and subsequent partial northward reoccupation of the original territory of the species. Not improbably, however, imparis in North America may have actually suffered very little displacement beyond the southern border of the ice-sheet. In this connection the ant's negative thermotropism might be supposed to have been acquired during the Glacial Epoch, but there seems to be another way of accounting for this resistance to cold, as I shall suggest in the sequel.

Emery has called attention to the resemblance of the present distribution of $P$. imparis to that of the ants of the Dolichoderine genus Liometopum. This is shown in the accompanying maps (Fig. 1 and 2). In the Old World the 
genus comprises two fossil and three extant species. In 1914 I described one of the former, L. oligocenicum, from the Baltic amber, and Mayr (1867) had previously described the other, L. antiquum, from the Radoboj-shales of Lower Miocene age.* The three living Old World species comprise, first, the wellknown $L$. microcephalum Panzer, which covers the range of $P$. imparis var. nitens but has a wider distribution, extending to Italy and Sicily, Southern Russia, the Eastern Caucasus and Turkestan and therefore occupying a territory enclosing the Adriatic, Black, Caspian and Aral Seas; second, L. lindgreeni Forel, inhabiting Assam and, according to Bingham, also Upper Burma; and third, L. sinense Wheeler, which seems to be widely distributed in Southern China. In North America there are three species, two fossil, namely miocenicum and scudderi, both recently described by Carpenter (1930) from the Miocene shales of Florissant, Colorado, and two living species, L. occidentale Emery of California and Oregon and L. apiculatum Mayr, with several subspecies, in part still undescribed, and ranging over the warmer lower slopes of the mountains from Southern Alberta to the State of Colima in Mexico, but not east of the hundredth meridian in the United States. The species of Liometopum are so closely interrelated that a conservative "lumper" might regard them all as varieties of a single species. Comparison of the two maps (Figs. 1 and 2) shows that the species of Liometopum, though discontinuous in their individual ranges, together occupy a much more extensive territory than the varieties of imparis. It will be seen also that the Liometopums are confined to xerothermal mountain areas. They are even more conspicuously associated with oaks than imparis, and build large, finely trabecular, carton nests in the cavities of their trunks. The colonies are very populous and aggressive, though frequently, at least in North America; harboring numerous Staphylinid myrmecophiles (Apteronina schmitti Wasm. and Dinardilla liometopi Wasm.). The velvety, strong-smelling workers forage in dense files on the vegetation where they secure honey-dew and miscellaneous insect food. For a more detailed account of the habits of

*I doubt the generic identification of this ant. The type is a female, described as only $5 \mathrm{~mm}$. long, whereas this sex in all the other species is much larger. Moreover, the workers of the still older oligocenicum are as large as those of the living species. I regard two other described fossil species from Radoboj, imhoffi Heer and schmidti Heer, as even less probably referable to the genus Liometopum. 
L. microcephalum the reader may be referred to the papers of Emery (1891) and Forel (1892) and for observations on $L$. apiculatum and occidentale to one of my early papers (1905).

While we may assume that the earliest known ancestors of both $P$. imparis and Liometopum are represented by $P$. henschei and $L$. oligocenicum respectively of the Baltic amber, it does not necessarily follow that the latter belonged to the same geological age. We have long known that among the amber insects there are two distinct faunal components, one closely related to our present circumpolar, north temperate species, the other more closely related to the tropical or subtropical species of the Indomalayan and Australian Regions. It has been assumed, therefore, either that the formation of the amber must have covered a long period with two different, successive climates, or that the specimens represent a mixture of contemporary forms which, however, actually lived at very different altitudes. That the ancient Samland was mountainous is indicated by Ulmer's study of the amber caddiceflies, which belorg partly to modern genera whose larvæ live in torrential waters and partly to those whose larvæ inhabit sluggish streams or pools. A palaeobotanist, Professor E: W. Berry (1927), has recently expressed himself as follows on the climatic conditions in which the amber forests flourished: "As I picture the amber forests from the evidence of the plants my picture agrees fairly well with that which modern authorities derive from a study of the insects, namely that we have a mixture of forms whose existing relatives still live at the same latitude with others whose relatives now live in warmer climes. Certainly, the climate was temperate and not in any sense tropical. This is clearly indicated by the abundance and variety of coniferous trees, as well as by the northern element in the insect faunas; but among them we find representatives of a number of warm temperate types, and I think we are justified in concluding that the climate was much more genial, and the floras and faunas much more extensive and varied than in the Samland of the present time."

The more southern distribution of both $P$. imparis and Liometopum at the present time as compared with their distribution during the Lower Oligocene not only confirms Berry's description of the Samland climate but also suggests that their range during the earlier Tertiary (Eocene and Paleocene) 
may have extended to an even higher latitude, where the climate was like that of Western Greenland as indicated by the studies of Seward (1927), who describes from that region Cretaceous remains of coniferous and quercine trees, if not of actual oaks. If Prenolepis and Liometopum were components of such a polar ant-fauna we can easily account for the present distribution of the two genera in both hemispheres. The resistance to cold on the part of $P$. imparis, therefore, may have been acquired during its long and very gradual southward displacement before the glacial period. The more xerothermal Liometopum is not improbably an older, Cretaceous genus which had reached its present habitat in Early Miocene times. The northern portion of the range of the New World species, apiculatum, was probably annexed after the recession of the glaciers.

\section{B. Taxonomy of $P$. imparis.}

As previously stated, this ant is so constant morphologically that it seems inadvisable to assign more than varietal, or subracial status to any of the forms that can be recognized among the materials in my collection. I therefore redescribe all three phases of the typical imparis and subjoin brief descriptions of the nine varieties, which in part at least, represent incipient geographical races. More material, especially from the Rocky Mountain states and northern Mexico, will probably reveal the existence of several additional varieties.

Prenolepis imparis (Say) Mayr.

(Fig. 3, Fig. 4a).

Formica imparis Say, Boston Journ. Nat. Hist. 1. 1836, p. 287, $q 0^{7}$.

(?) Tapinoma polita F. Smith, Trans. Ent. Soc. London (2) 3,1855, p. 112 , ; Dale, Ent. Month. Mag. 17, 1881, p. 236, छ ; White, Ants and Their Ways, 1883, p. 257.

Formica (Tapinoma) Wichita Buckley, Proc. Ent. Soc. Phila. 6, 1866, p. 169,

(?) Tapinoma nitens E. Saunders, Trans. Ent. Soc. London, 1880, p. 211, \&; Ent. Month. Mag. 20, 1881, p. 270,

Prenolepis nitens Mayr., Verh. Zool. Bot. Ges. Wien. 36, 1886, p. 431, \&.

Prenolepis imparis Mayr. Ibid. 36, 1886, p. 431, \%; Dalla Torre, Cat. Hymen. 7, 1893 , p. 178, 웅 o : Emery, Zool. Jahrb. Abt. Syst. 7, 1893, p. 635, \& o o'; Wheeler, Bull. Amer. Mus. Nat. Hist. 21, 1905, p. 390, fig. 1, \& o ; Occas. Pap. Boston Soc. Nat. Hist. 7, 1906, p. 11; Psyche 20, 1913, p. 116; Proc. Amer. Acad. Arts Sc. 52, 1917, p. 523; Emery, Gen. Insect. Formicinæ, 1925, p. 225, $\forall$ o $0^{7}$.

Prenolepis nitens var. americana Fore1, in Grandidier, Hist. Madagascar 20, 1891, p. 94 , P1. 3, fig. 4, o'.

Prenolepis (Nylanderia) imparis Emery, Ann. Soc. Ent. Belg. 50, 1906, p. 133, 134; Wheeler, Bull. Amer. Mus. Nat. Hist. 24, 1908, p. 385, fig. 26, 
Worker. Length 3-4 mm.

Head as broad as long, slightly narrower in front than behind, with straight posterior border and feebly rounded sides and posterior corners. Eyes moderately convex, nearly one-fourth as long as the sides of the head, and situated a little behind its middle. Mandibles rather flat, with convex external borders, their apical borders feebly oblique, 6 -toothed, the apicial and basal tooth largest, the former strongly curved, the third tooth from the tip minute. Maxillary palpi very long, reaching to the occipital foramen. Clypeus convex in the middle, subcarinate behind, depressed on the sides, its anterior border broadly rounded and entire. Frontal area large but indistinctly defined; frontal groove absent; frontal carinæ feeble, short and subparallel. Antennæ slender; scapes extending about two-fifths their length beyond the posterior corner:s of the head; first funicular joint as long as the subequal second and third together; joints $2-8$ nearly twice as long as broad, remaining joints somewhat shorter, except the last, which is as long as the two pentiltimate joints. Thorax small and slender, divided into two portions by a deep constriction of the posterior part of the mesonotum; the promesonotum somewhat longer than broad, evenly convex and subhemispherical above, the dorsal outline not interrupted at the promesonotal suture, the mesonotum anteriorly as long as broad, subtrapezoidal, a little broader in front than behind, sloping downward and passing posteriorly into the constricted portion which bears on its dorsal surface the pair of somewhat projecting metathoracic spiracles close to the base of the epinotum. The latter is subrectangular from above and nearly as broad as long, in profile with subequal base and declivity, the former slightly convex and rising posteriorly where it has a faint longitudinal impression and forms a distinct but rounded angle with the declivity. This is broad and flat, with its projecting spiracles near the middle of its sides. Petiole as long as high, its node strongly inclined forward, in profile compressed and cuneate, with feebly convex anterior and posterior surfaces and rather acute border; seen from behind it is trapezoidal, broader above than below, with straight sides and a transverse superior border, which is straight or very slightly concave in the middle. Gaster proportionally large, broad anteriorly, tapering behind to a point, convex above, the basal segment concave anteriorly where it overlies the petiole, its anterior border above straight and transverse in the middle and forming a distinct angle on each side. Legs rather slender.

Very smooth and shining; mandibles glossy, very finely longitudinally striate; head and thorax with small, sparse, piligerous punctures; gaster very finely, superficially and tranversely shagreened, with coarser piligerous punctures, and along the posterior borders of the segments with minute, hair-bearing tubercles.

Hairs and pubescence whitish or pale yellowish, the former rather coarse, erect or suberect, pointed, of unequal length, more abundant on the head and gaster than on the thorax, longest on the gaster. Cheeks, gula and front also with conspicuous short, sparse, appressed hairs, or very coarse pubescence. Antennæ with abundant fine, oblique 
hairs or pubescence, longest and most conspicuous towards the tips of the scapes. Legs with very short, sparse, inconspicuous, appressed or subappressed pubescence.

Varying from pale castaneous to dark piceous brown, the thorax and anterior portion of the head usually paler, the gaster darker and more blackish; mandibles, antennæ, legs, including coxæe and posterior edges of gastric segments, brownish yellow or yellowish brown. Palpi pale yellow, mandibular teeth black.

Female. Length $7.5-8.5 \mathrm{~mm}$; wings $7-7.5 \mathrm{~mm}$.

Head broader than long and more narrowed anteriorly than in the worker. Eyes rather large; ocelli small and close together. Thorax massive, broader than the head, from above broadly elliptical, dorsally somewhat flattened in profile; mesonotum as long as broad; scutellum large; epinotum small, subperpendicular, rounded, without base or declivity. Petiolar node broad, thick below, strongly anteroposteriorly compressed above, its superior border deeply excised in the middle. Gaster large, oblong-elliptical, its basal segment angulate on each side anteriorly as in the worker.

Less shining than the worker, with the mandibles more coarsely striate and the head, thorax and gaster much more densely punctate.

Erect hairs shorter and more numerous than in the worker. Head, thorax and gaster covered with yellowish appressed pubescence which, however, is not sufficiently dense to conceal the shining and punctate integument. A similar but somewhat shorter pubescence covers the antennæ and legs.

Reddish brown; mandibles, antennæe and legs slightly paler and more reddish. Wing membranes uniformly yellowish brown; veins and pterostigma resin-colored.

Male. Length $3.5^{-4} \mathrm{~mm}$.

Head, including the eyes, broader than long, broadly rounded behind, without posterior corners, narrowed anteriorly, with short, straight cheeks. Mandibles rather large and overlapping, but with only the apical tooth developed. Clypeus large, less convex than in the worker. Antennal scapes slender, about one-third as long as the long funiculus; first joint of the latter small, of the usual shape, about one and one-half times as long as broad; remaining joints broader, of uniform width, twice as long as broad, the penultimate joints somewhat shorter, the last as long as the two preceding joints together. Thorax not broader than the head; mesonotum convex anteriorly, distinctly broader than long; epinotum evenly rounded and sloping in profile, without distinct base and declivity. Petiolar node shaped somewhat as in the worker, but much thicker, inclined forward, with blunt apical border, straight and transverse but not impressed in the middle. Gaster elongate-elliptical; external genital appendages long, somewhat curved, uniformly tapering and blunt at the tip. Legs slender; hind tibiæ feebly bent near the middle.

Shining and finely punctate; antennæ and legs more finely and densely than the remainder of the body; mandibles very finely striate as in the worker. 
Hairs grayish, rather soft and flexuous, long and abundant on the head and thorax and very conspicuous on the tip and venter of the gaster. Pubescence long, sparse and appressed, most distinct on the gaster, very fine and short on the legs, slightly longer and more oblique on the scapes.

Piceous black; antennæ and mandibles dark brown; femora black, the trochanters, tips of femora, the tibia and tarsi brownish yellow. Wings varying in co.or from whitish to grayish hyaline, with colorless or pale yellowish veins and pterostigma.
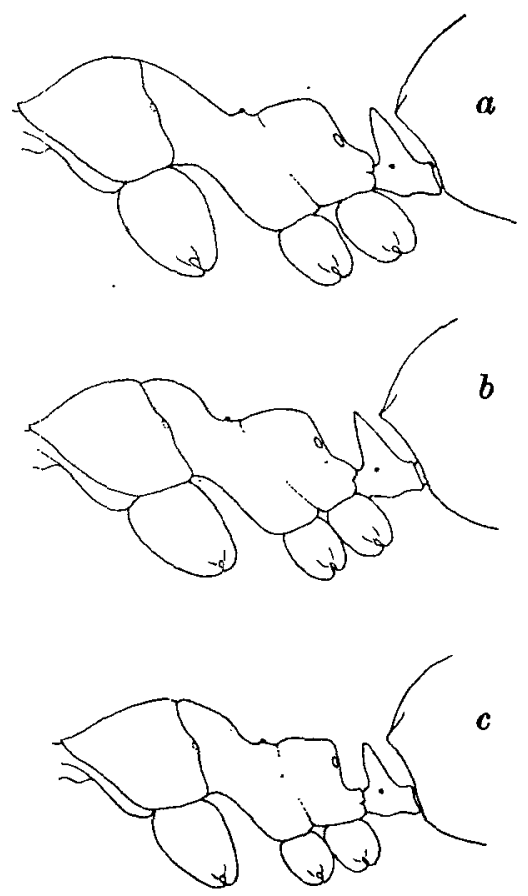

Fig. 4. a., Thorax and petiole of worker Prenolepis imparis sens. str. in profile; $b$., same of the var. californica var. nov.; $c$., same of the var. coloradensis var. nov.

The type-loca'ity of $P$. imparis sens. str. is "Indiana." I have seen no specimens of this ant from that state, but have series or records from the following localities, which show that it is widely distributed over the eastern half of the United States and Southern Ontario, from Massachusetts to Missouri and south to Georgia, Mississippi and Texas:

Ontario: Grimsby.

Ohio: Hocking County (M. R. Smith).

Pennsylvania: Beatty (J. Schmitt); Harrisburg.

New Jersey: Fort Lee and Halifax (W. M. Wheeler); Clementon; Ramsey; Burlington (T. J. Headlee); Caldwell (Cresson); Camden County (Fox). 
New York: Central Park, New York City and Brooklyn (H. von Krockow), Bronxville and Cold Spring Harbor, L. I. (W. M. Wheeler); Wyandach, L. I. (F. M. Schott); Conesus, Clinton Heights; Callicoon, White Plains and Van Cortland Park (J. Bequaert); Tottenville, New Brighton, Watchogue, Long Neck and Annandale, S. I. (W. T. Davis and J. Bequaert); Amagansett, Yaphank, Calverton, Montank, Pinelawn, Wading R., Gardner's I. and Cold Spring Harbor, L. I. (W. T. Davis and J. Bequaert).

Maryland: District of Columbia (T. Pergande); Plummer's I. (W. L. McAtee).

North Carolina: Tryon (W. M. Wheeler); Black Mt. (B. Muller); Lake Toxoway (Mrs. A. T. Slosson).

Georgia: Thomasville; Clayton, 2,000-3,700 ft. (W. T. Davis).

Mississippi: Holly Springs (T. F. McGehee).

Connecticut: New Haven and Yalesville (H. Viereck); Branford (Winckley); New Haven (Britton).

Massachusetts: Forest Hills and Blue Hills (W. M. and G. C. Wheeler); Danvers (H. W. Winckley); Wareham (C. A. Frost); Milton (A. P. Morse); Essex County and Springfield (G. B. King); Warwick (Miss Edmonds); Woods Hole and Falmouth (A. H. Sturtevant).

Illinois: Rockford (W. M. Wheeler).

Wisconsin: Wauwatosa (G. Graenicher).

Missouri: Jefferson City (A. C. Burrill).

Kansas: Douglas County (C. Klaumann); Lawrence (Tucker); Riley County (J. B. Norton).

Texas: Denton (W. H. Long).

\section{P. imparis var. nitens (Mayr.)}

Tapinoma nitens Mayr, Verh. Zool. Bot. Ges. Wien. 2, 1852, p. 144, 8 ; Ibid. 5, 1855, p. 377, ; Progr. Realsch. Pest. 1856, p. 15,

(?) Tapinoma polita F. Smith, Trans. Ent. Soc. London (2) 3, 1855, p. 112,

Prenolepis nitens Mayr, Europ. Formicid. 1861, p. 52, ¥; Ern. André, Spec. Hymen. Europ. 2, 1882, p. 204-206, o o $\sigma^{7}$; Emery, Bull. Soc. Ent. Ital. 47, 1918, p. 238 , Fig. 78, $\sigma^{7}$; Genera Insect. Formicinæ, 1925, p. 225, $\$ \sigma^{7}$.

(?) Tapinoma nitens E. Saunders, Trans. Ent. Soc. London, 1880, p. 211, \& ; Ent. Month. Mag. 20, 1881, p. 270, .

Prenolepis imparis var. nitens, Dalla Torre, Cat. Hymen. 7, 1893, p. 178, \& o $\sigma^{7}$; Ruzsky, Formicar. Imper. Ross. 1905, p. 262, fig. 50, 51, o o ot.

Prenolepis imparis subsp. nitens Emery, Deutsch. Ent. Zeitschr. 1910, p. 128, fig. 1 , 8 o $0^{7}$.

Formica crepusculascens Roger, Berlin. Ent. Zeitschr. 3, 1859, p. 238, o ; Ibid. 6, 1862 , p. $256, \sigma^{7}$.

Lasius (?) crepusculascens Mayr, Europ. Formicid. 1861, p. 51, 우

Worker. Length 3-3.5 mm.

Very similar to the common dark form of the typical imparis. Brown, with piceous black gaster; antennæ somewhat paler and more yellowish brown than the head and thorax. Superior border of petiolar node somewhat more impressed in the middle. Pilosity and pubescence very similar but the legs have somewhat longer and more oblique, i.e. less appressed, hairs and the pubescence on the antenn $x$ is perhaps slightly longer and denser.

Female. Length $9 \mathrm{~mm}$; wings $8.5 \mathrm{~mm}$.

Very similar to the female of the typical imparis but apparently darker, being piceous instead of reddish brown; the wings also darker brown, with dark brown viens and pterostigma. Pubescence on the antennæ and legs somewhat shorter and more appressed than in the worker. 
Male. Length 3-3.5 mm.

Also very similar to the male of imparis sens. str. and also black or dark piceous brown, but the wings are darker, being tinged with brown and having pale brown veins and pterostigma. The tibire, too, are darker and more brownish. Pilosity and pubescence very similar.

Northeastern corner of Italy, Tyrol, Austria, , Balkan Penninsula, Asia Minor and Caucasus.

The description of the female, which I have not seen, is adapted from Emery.

\section{P. imparis var. testacea Emery.}

Prenolepis imparis var. testacea Emery, Zool. Jahrb. Abt. Syst. 7, 1893, p. 636 , \& $0^{7}$; Wheeler, Bull. Amer. Mus. Nat. Hist. 21, 1905, p. 390, \&; Psyche 30. 1913 , p. 116, \&; Enery, Genera Insect. Formicinæ, 1925, p. 225, \&; M. R, Smith, Ent. News, 39, 1928, p. 278, 8 .

Worker. Differing from the typical imparis in color, being yellow, or brownish or reddish yellow, with the gaster and posterior portion of the head often darker and varying from pale to dark brown. Legs yellow. Quite as smooth and shining as the type, with the same pubescence and pilosity.

Female. Distinctly paler and more yellowish red than the typical imparis; mesonotum with a broad brown parapsidal streak on each side and often with a narrower antero-median streak of the same color. Wings of the same yellowish brown tinge as in imparis, with resincolored veins and pterostigma.

Male. Brown or yellowish brown, with darker head; legs yellow, with the femora brownish except at their tips; antennæe of the same color as the body. Wings slightly tinged with yellowish; veins and pterostigma brownish.

District of Columbia: Washington (T. Pergande), type-locality.

Virginia: (T. Pergande).

North Carolina: Tryon (W. M. Wheeler); Black Mt. and Swannanoa (W. Beutenmueller).

Georgia: Clayton, 2,000-3,700 ft. (W. T. Davis); Gainesville, Tybee Is1., Marietta and Atlanta (J. C. Bradley).

Florida: St. Augustine (C. T. Brues); Tallahassee.

Mississippi: Agricultural and Mechanical College (M. R. Smith).

New Jersey: Lakehurst (W. T. Davis and W. M. Wheeler); Clementon and Medford ( $\mathrm{H}$. Viereck).

New York: Mosholu, Bronxville, Van Cortland Park, Central Park, New York City and Arlington, S. I. (W. M. Wheeler); Tottenville, S. I., Wading R. and Amagansett, L. I. (W. T. Davis and J. Bequaert); Ithaca (Funkhauser); Taughannoc Falls, Tthaca (C. P. Haskins).

Pennsylvania: Beatty (J. Schmitt).

Missouri: Columbia (A. M. Ferguson).

Arizona: Indian Garden, Grand Canyon (W. M. Wheeler).

Unlike the typical imparis, testacea prefers to nest in pure sand or sandy soil at low altitudes. Its distribution shows 
that it is a southern form, most abundant in the Carolinian area of Southern New Jersey and southward to Florida.

\section{P. imparis var. minuta Emery.}

Prenolepis imparis var. minuta Emery, Zool. Jahrb. Abt. Syst. 7, 1893, p. 636, \& $0^{7}$; Wheeler, Occas. Papers Boston Soc. Nat. Hist. 7, 1906, p. 11, $;$; Emery, Genera Insect. Formicinæ, 1925, p. 225, $₫ \sigma^{7}$.

Worker. Length $2-2.5 \mathrm{~mm}$.

Closely resembling the typical imparis in sculpture, pilosity and color but decidedly smaller.

Female. (undescribed). Length $6.5 \mathrm{~mm}$.; wings $6.5 \mathrm{~mm}$.

Also smaller than the females of any of the preceding forms, somewhat paler than imparis and darker than lestacea, with the mesonotal markings of the latter and the wing-membranes somewhat paler than in either of these forms.

Male. Length $2.5 \mathrm{~mm}$.

Indistinguishable from the male of imparis, except in its smaller size and in having slightly darker wings. Veins and pterostigma pale yellowish.

District of Columbia: · (T. Pergande), type-locality.

North Carolina: Clemson Agricultural College, (M. R. Smith and W. A. Morrison). New Jersey: Cape May and Bridgetown (F. M. Schott).

Connecticut: New Haven and Yalesville (H. Viereck).

Indiana: Hammond and Wyandotte (W. Blatchley).

Wisconsin: Alma Center (A. C. Burrili).

Missouri: Barton County (J. W. Chapman).

Washington and Oregon: Columbia River Gorge (A. C. Burrill).

I possess two worker cotypes from the District of Columbia, two males from Cape May and Bridgetown, N. J., and a single female from the latter locality. In stature this variety, which has a wide distribution though it seems to be rather rare, closely resembles $P$. heinschei of the Baltic Amber. The same is true of the following small variety.

\section{P. imparis var. pumila var. nov.}

Worker. Length $2.2-2.5 \mathrm{~mm}$.

Of the same pale color as the var. testacea and bearing to it the same relationship in stature that the var. minuta bears to the typical imparis. The gaster, however, is paler and only slightly infuscated across the middle of each segment. Legs and antennæ pale yellow.

Male. Length $2.3-2.5 \mathrm{~mm}$.

Coiored like the male testacea but smaller; reddish brown; head darker brown posteriorly; femora, except their tips, brown like the thorax. Wings grayish hyaline, with pale brownish veins.

North Carolina: Raleigh (F. Sherman), type-locality.

Alabama: Fort Payne (W. S. Creighton).

District of Columbia: Washington (T. Pergande).

New York: New York City (C. T. Brues). 


\section{P. imparis var. coloradensis var. nov.}

(Fig. 4, c).

Worker. Length $2.5-3 \mathrm{~mm}$.

Resembling the var. pumila but averaging somewhat larger and darker in color, being brown, with the gaster and posterior portion of the head scarcely darker than the thorax; posterior borders of gastric segments, antennæe and legs yellow. Distinguished from all the preceding formis by the shape of the epinotum, which has the base decidedly shorter than the declivity and forming with it a much more pronounced angle, almost a right angle, in fact, because the declivity is much more nearly perpendicular. Upper border of petiolar node seen from behind straight and transverse, with less rounded corners.

Numerous specimens from Cheyenne Mt., $8000 \mathrm{ft}$, near Colorado Springs, Colorado (W. M. Wheeler).

\section{P. imparis var, arizonica var. nov.}

Worker. Length 3-3.5 mm.

Of the same color as darker specimens of the var. testacea; thoracic sutures, mandibles, coxæ, legs and antennæ brownish yellow. Pilosity distinctly longer and on the gaster conspicuously more abundant; pubescence on antennal scapes somewhat longer. Upper border of petiolar scale distinctly concave in the middle. Base of epinotum rather short but in other respects the thorax is shaped as in the typical imparis and the var. lestacea.

Female. Length $6.5 \mathrm{~mm}$.; wings $7.5 \mathrm{~mm}$.

Smaller than the female of imparis, its vars. nitens and testacea and colored like the last, but without mesonotal markings. Wings quite as dark but less yellowish and with brownish yellow veins and brown pterostigma. Pubescence on head, thorax and gaster much longer. Petiolar node broader, with more rounded sides above and distinctly narrower and shallower emargination in its superior border.

Male. Length $3-3.2 \mathrm{~mm}$.

Dark piceous brown, with black head; antennæ and legs throughout as dark as the thorax and gaster. Wings decidedly darker than those of any of the preceding forms, including the var. nitens, uniformly dark gravish, with dark brown veins and pterostigma.

Described from four workers, three males and a single female taken by Dr. W. M. Mann in Ramsay Canyon, Huachuca Mts. $5800 \mathrm{ft}$. Arizona. In all probability, this form occurs also in the mountains of northern Mexico. 


\section{P. imparis var. californica var. nov.}

(Fig. 4, b).

Worker. Length $2.3-2.5 \mathrm{~mm}$.

Averaging smaller than the typical imparis and usually of the same color, but often darker and almost black, more rarely paler and approaching the var. testacea. Antennæ and legs brown, tarsi paler and more yellowish. Eyes distinctly smaller, mesonotum more convex, so that the curved dorsal outline is more interrupted at the promesonotal suture than in imparis; the constricted posterior portion of the mesonotum very short and the metathoracic spiracles therefore closer to the posterior end of the mesonotal declivity. Petiolar node narrower, more compressed anteroposteriorly, with more flattened anterior and posterior surfaces and sharper superior border. The latter less transverse, not concave. Long pilosity on the body much as in imparis, the pubescence on the scapes and legs longer and less appressed.

Female. Length $6-6.5 \mathrm{~mm}$; wings $7.3 \mathrm{~mm}$.

Smaller than the female of the typical imparis; either dark brown and therefore of the same color or paler and more reddish. Wings darker and more brownish, with brown veins and pterostigma. Thorax somewhat broader and higher; petiolar node thinner, with less deeply excised superior border.

Male. Length $2.8-3.2 \mathrm{~mm}$.

Also smaller than the male of the typical imparis; black or piceous black, with brown antenna and legs, tarsi and knees somewhat paler. Wings gray, darker than in the typical imparis, with more distinct brown veins and pterostigma, as in the var. nitens. Erect pilosity abundant on the head, thoracic dorsum and gaster, very conspicuous on the venter. Eyes somewhat smaller and less convex than in imparis; petiolar node not so thick above.

California: Stanford University (H. Heath, W. M. Mann, C. F. Baker), typelocality; San Jose (H. Heath); Marin County; Eldridge, Sonoma County (J. A. Kusche); Piedmont and Berkeley (J. C. Bradley); mountains near Claremont (C. F. Baker); Santa Cruz Island (R. V. Chamberlin); Point Loma,

San Diego (P. Leonard); Santa Inez Mts. and San Ysidro, near Santa Barbara, Pasadena, Mt. Lowe and Yosemite Village (W. M. Wheeler); Santa Paula

(H. F. Quayle); Portola; La Verne (E. Becker).

Nevada: Ormsby County (C. F. Baker).

Oregon: Ashland (W. Taverner); Forest Grove (A. C. Burrill).

This form, which seems to be confined to the Pacific coast region, is rather unstable and may have to be resolved into several distinct varieties when more material, especially of the females and males, is available for study. The workers from La Verne, Calif. are very dark, those from Santa Cruz Island and Point Loma approach the var. testacea in color, but those from the vicinity of San Francisco are colored like the typical imparis. The specimens which I collected on Mt. Lowe are 
reddish brown and vary greatly in size (from $2-3.5 \mathrm{~mm}$.). They have unustually long and suberect pubescence on the scapes and legs and seem, therefore, to be transitional to the following two varieties from Mexico.

\section{P. imparis var. veracruzensis var. nov.}

Worker. Length $3 \mathrm{~mm}$.

Resembling the typical imparis but uniformly brownish red, except the tarsi and knees, which are yellow. Head subrectangular, as broad in front as behind. Promesonotum and petiole shaped as in imparis; base of epinotum more convex, rising posteriorly and rounding into the longer declivity without any indication of an angle. Pubescence on scapes and legs long, conspicuous and less appressed, even longer than in the above-rnentioned form of californica from Mt. Lowe.

Described from a single specimen taken in sweepings by Dr. A. Dampf at Maltrata, Altaluz, in the State of Vera Cruz, Mexico. Till more material is available the status of this variety is problematic. It is obviously closely related to the following:

\section{P. imparis var. colimana var. nov.}

Worker. Length 3-3.5 mm.

At first sight resembling dark forms of the typical imparis. Rich castaneous brown, the posterior portion of the head and the gaster darker and more blackish; antennæ, trochanters, tarsi and bases and tips of femora paler, more yellowish brown. Head, thorax and petiole shaped as in imparis, but stouter. Erect hairs on the body longer and more abundant and the pubescence on the scapes and legs much longer, more abundant and more nearly erect than in any of the other varieties. The scapes appear plumose, owing to their pubescence being longer than their greatest diameter and even the funiculi have unusually long and conspicuous pubescence.

Described from numerous specimens taken by Mr. C. H. T. Townsend on the Volcan de Colima at an altitude of $7500 \mathrm{ft}$., in the state of Colima, Mexico. 


\section{LITERATURE}

1927. Berry, E. W. The Baltic Amber Deposits. Scient. Monthl. 24, 1927, pp. 268-278, 3 figs.

1906. Bingham, C. T. Formicidae in "The Wild Fauna and Flora of the Kew Botanic Gardens." Bull. Misc. Inform. Roy. Bot. Gard. Kew Addit. Ser. 5, 1906, pp. 27-29.

1887. Bos, H. Iets over de Nederlandsche Mierenfauna. Tijdschr. v. Ent. 30, 1887, pp. 181-198.

1930. Carpenter, F. M. Fossil Ants of North America. Bull. Mus. Comp. Zool. 70,1930 pp. 3-66, 11 pls.

1908. Donisthorpe, H. S. J. K. Ants found in Great Britain. Trans. Leicester Lit. Phil. Soc. 12, 1908, pp. 221-233.

1927. Donisthorpe, H. S. J. K. British Ants, their Life-history and Classification, 2nd edit. London, 1927.

1891. Emery, C. Zur Biologie der Ameisen. Biol. Centralbl. 11, 1891, pp. $168-173$.

1893. Emery, C. Beiträge zur Kenntnis der nordamerikanischen Ameisen. Zool. Jahrb. Abth. Syst. 7, 1893, pp. 633-682, 1 pl.

1906. Emery, C. Note sur Prenolepis vividula Nyl. et sur la classification des espèces du genre Prenolepis. Ann. Soc. Ent. Belg. 50, 1906, pp. 13-134, 5 figs.

1910. Emery, C. Beiträge zur Monographie der Formiciden des paläarktischen Faunengebietes. 'Teil X. Deutsch. Ent. Zeitschr. 1910, pp. 127-132, 9 figs.

1916. Emery, C. Fauna Entomologica Italiana. Formicidae. Bull Soc. Ent. Ital. 47, 1916. 201 pp., 92 figs.

1920. Emery, C. La distribuzione geographica attuale delle Formiche. Real. Accad. der Lincei 317,1920 , pp. 357-450.

1925. Emery, C. Genera Insectorum. Subfamily Formicinae. 1925.

1921. Finzi, B. Primo contributo allo conoscenza della fauna mirmecologica della Venezia Julia. Boll. Soc. Ent. Ital. 53, 1921, pp. 1-3.

1921. Finzi, B. Terzo contributo alla conoscenza della fauna mirmecologica della Venezia Julia. Boll. Soc. Ent. Ital. 59, 1927, pp. 7-10.

1926. Ford, N. On the Behavior of Grylloblatta. Canad. Ent. 58, 1926, pp. 66-70, 1 fig.

1886. Forel, A. Nouvelles fourmis de Grèce récoltées par M. E. von Oertzen. C. R. Soc. Ent. Belg., 1886, 10 pp.

1888. Forel, A. Ameisen aus den Sporaden; den Cycladen und Greichenland gesammelt von Herrn von Oertzen. Berlin. Ent. Zeitschr. 32, 1886, pp. 255-265.

1892. Forel, A. Die Ameisenfauna Bulgariens. Verh. zool. bot. Ges. Wien. 42, 1892, pp. 308-309.

1913. Forel, A. Fourmis de la fauna méditerranéenne récoltées par MM. U. et J. Sahlberg. Rev. Suisse Zool. 21, 1913, pp. 427-438.

1929. Frison, T. H. Fall and Winter Stoneflies, or Plecoptera, of Illinois. State Illinois Dept. Registr. Educ. Nat. Hist. Survey 18, 1929, pp. 345-409, 77 figs.

1928. Holmquist, A. M. Studies in Arthropod Hibernation. II. The Hibernation of the Ant, Formica ulkei Emery. Physiol. Zool. 1, 1928, pp. 325-357, 5 figs.

1925. Kusnezov-Ugamsky, N. Der Nestbau turkestanischer Ameisen als ökologischer Verbreitungsfaktor. Zool. Anzeig. 64, 1925, pp. 253-260.

1926. Kusnezov-Ugamsky, N. The Geographical Relations of the myrmecological Fauna of the Caucasus (in Russian) (period ?), 1926, pp. 63-74.

1927. Kusnezov-Ugamsky, N. On the Marriage Flight of Ants. (In Russian). Rev. Zool. Russe 7, 1927, pp. 77-104.

1929. Kusnezov-Ugamsky, N. The Ants of the Genus Messor in the Fauna of Middle Asia. Act. Univ. Asiae Mediae, ser. 8a, 1929, 25 pp., 3 pls.

1852. Mayr, G. Beschreibung einiger neuen Ameisen. Verh. zool. bot. Ges. Wien. 2, 1852, p. 143-150. 
1855. Mayr, G. Formicina austriaca. Verh. zool. bot. Ges. Wien. 5, 1855, pp. $273-478,1 \mathrm{pl}$.

1861. Mayr, G. Die Europäischen Formiciden. Wien 1861 , VIII + 80 pp., 1 p1.

1867. Mayr, G. Verläufige Studien über die Radoboj-Formiciden. Jahrb. K. K. geol. Reichsan. Wien 17, 1867, pp. 47062, 1 pl.

1886. Mayr, G. Die Formiciden der Vereinigten Staaten von Nordamerika. Verh. zool. bot. Ges. Wien 36, 1886, pp. 419-464.

1905. Ruzsky, N. Formicariae Imperii Rossici. (In Russian). Kasan, 1905.

1910. Santschi, F. Contributions à la faune Entomologique de la Roumanie. Bul. Soc. Stiinte, 1910, pp. 648-651.

1835. Say, T. Descriptions of New North American Hymenoptera and Observations on Some Already Described. Boston Journ. Nat. Soc. 1, 1835, pp. 210-305.

1927. Seward, A. C. Plant-bearing Rocks of Western Greenland. Phil. Trans. Roy. Soc. London B, 215, 1927, pp. 57-175, 9 pls.

1925. Steiner, A. Temperaturmessungen in den Nestern der Waldameise (Formica rufa var. rufo-pratensus For.) und der Wegameise (Lasius niger L.) Wahrend des Winters. Mitteil. Naturf. Gesell. Bern., 1925, pp. 1-12.

1929. Steiner, A. Temperaturmessungen in Ameisennestern mit Erdkuppeln, im Nest von. Formica exsecta Nyl. and in Nestern unter Steinen. Zeitschr. vergleich Physiol. 9, 1929, pp. 1-66, 25 figs.

1905. Wheeler, W. M. The North American Ants of the Genus Liometopum. Bull. Amer. Mus. Nat. Hist. 21, 1905, pp. 321-333, 3 figs.

1908. Wheeler, W. M. Honey Ants, with a Revision of the American Myrmecocysti. Bul... Mus. Nat. Hist. 24, 1908, pp. 345-397, 28 figs.

1910. Wheeler, W. M. Ants, their Structure, Development and Behavior. New York, 1910.

1914. Wheeler, W. M. The Ants of the Baltic Amber. Schrift physika1. okonom. Gesell. Konigsberg 55, 1914, pp. 1-142, 66 figs.

1917. Wheeler, W. M. Notes on the Marriage Flights of Some Sonoran Ants. Psyche 24, 1917, pp. 177-180. 